\title{
WEALTH AND WISDOM IN MATTHEW 6:19-34
}

\section{Batara Sihombing}

This dissertation has three objectives. First, it demonstrates that the background to Matthew 6:19-34 can be found in the Jewish wisdom literature of the Hebrew Bible, Apocrypha, Pseudepigrapha, and Dead Sea Scrolls. Parallel ideas about money include that those who love money will never find satisfaction (Prov. 8:17-21; Eccl. 5:9-11); they will be taken captive by it (Sir. 31:5; 4QInstruction ${ }^{\text {b }}$, II, 17-18); the love of money will lead to idolatry (T. Jud. 19:1; 17:1; 18:2); and the love of money is the mother of all evil (Ps.-Phoc. 42-47). Other parallels include Wisdom literature's encouragement to pursue wisdom because it is greater than any earthly value (Wis. 7:7-14; cf. Matt. $6: 33)$; to share possessions with others in need, according to the principles of willingness and proportion (Tob. 4:6-7; cf. Matt. 6:22-23).

Second, the dissertation shows that the subject of wealth is central to Matthew 6:19-34. The first part (vv. 19-24) contains a triad on the nature of true treasure (Matt. 6:19-24) and the second part (vv. 25-34) encourages people to overcome anxiety. From a form-critical point of view the themes of Matthew 6:19-34 echo Jewish wisdom tradition and a redaction-critical point of view demonstrates that the arrangement of Matthew 6:19-34 relates to the question of wealth. It encourages people to know the true treasure (Matt. 6:19-24) and to live as God's children by ignoring anxiety (Matt. 6:24-34), serving God (Matt. 6:24) and seeking his kingdom first (Matt. 6:33). Jesus' wisdom teaching is much closer to the Jewish wisdom tradition than to that of Greek Cynics. The principle of two ways (Prov. 4:10-14) can be found in treasures in heaven or on earth (Matt. 6:19-21), the sound or unsound eye (Matt. 6:22-23), God or mammon (Matt. 6:24), and being God's children or like the Gentiles (Matt. 6:32). Theologically the theme of one God

1 Abstract of a dissertation for the degree of Doctor of Theology for the South East Asia Graduate School of Theology, Trinity Theological College, Singapore, 2005. 
(Matt. 6:24; 22:37) is rivalry to mammon which becomes a pseudodeity.

Third, the dissertation highlights the concept of wealth among the Toba Bataks in Indonesia. Wealth (honour, riches, and fecundity) is regarded as one of the highest ideals because the Bataks believe that getting rich is the way to become authoritative in the community. Batak proverbs (umpama) illustrate this ambition to be wealthy, though several proverbs suggest that to be rich in sinful ways is wrong.

The practice of auction in the Batak churches may be regarded as an example of the importance the Bataks place on wealth. Even though these auctions show co-operative activity in collecting money, they are difficult to reconcile with what Jesus says about offering money to God (cf. Matt. 6:2-4; cf. Prov. 8:18-21; Sir. 31:1-17). Apart from obscuring the real meaning of making offerings to God (Tob. 4:7, 16; cf. 2 Cor. $8: 11-12 ; 9: 5-7)$, the practice of auction creates social divisions in the gathering of the believers, which is counter to the principle of equality (Gal. 3:26-28; 1 Cor. 12:13; Col. 3:10-11).

Another negative impact of wealth can be seen in the existence of patrons in the Batak churches. Since rich people are honoured in society, patrons are very powerful in the churches, especially those who contribute substantially to church funds. The role of patrons can bring conflict in the community since they tend to be dictatorial. Believers should glorify only the head of the church, Jesus Christ (cf. Acts 17:7; Eph. 1:10, 22; Col. 1:18; 2:10; 1 Tim. 6:15) and serve him instead of demonic forces such as mammon or wealth (Matt. 6:24; cf. Ps.-Phoc. 44-47; 4QInstruction ${ }^{\mathrm{b}} 2$ II, 14-15).

The longing for wealth entices people to try to obtain any earthly treasures that can give an advantage. One reason why Indonesia has changed from a developing country to a poor country is the corruption which is widespread in society, including among the Bataks. As Wisdom literature and the Sermon on the Mount teach that greedy people are never satisfied with what they have (Sir. 31:1-7; Matt. 6:2223) and wealth is a blessing from God so long as it is obtained by righteousness, justice, and wisdom (Prov. 8:17-21; 16:8; Sir. 31:8-11). Batak Christians have an important role raising Indonesia from its moral bankruptcy by avoiding corruption and serving God alone rather than mammon or wealth. 